\title{
Federalism
}

\section{Still Matters:}

The Securities

Reference Case

\section{Moin A. Yahya}

\section{Introduction}

In Canada, the financial industry rests upon "four pillars." These are the securities, insurance, trust, and banking sectors. The first three have been, historically, regulated at the provincial level under the rubric of "property and civil rights," while the fourth has been federally regulated under section 91(15) of the Constitution Act, $1867 .^{2}$ As early as 1935 , however, a Royal Commission recommended the establishment of a federal securities agency tasked with overseeing federally incorporated companies. ${ }^{3}$ Nothing came of that. In the 1960s and until last year, numerous other studies came up with proposals regarding the establishment of a federal securities regulator. ${ }^{4}$ Some proposed a federal regular coexisting with provincial counterparts, while others proposed one single federal regulator. How to get the provinces on board varied depending on the study that was conducted.

Finally, in 2009 another study was released recommending the creation of a single federal regulator that would oversee all matters relating to securities in Canada. ${ }^{5}$ In order to convince the provinces to give up their role in the regulation of securities, an "opt-in" approach was suggested. This approach meant that the federal legislation would only apply in those provinces that agreed to give up their regulatory role over securities. Based on this panel's recommendations, the federal government prepared a draft
Act that would enact these recommendations. ${ }^{6}$ It also decided to refer the draft Act to the Supreme Court to test its constitutional validity. Provincial challenges, also through references, were also brought in Quebec and Alberta. The result was two appellate decisions and one $\mathrm{Su}-$ preme Court decision. ${ }^{7}$ All three cases found the draft Act to be unconstitutional.

This paper will provide a brief overview of the reasons behind the Supreme Court's ruling on the draft Act. Section 2 will provide an overview of the draft legislation. Section 3 will outline the basic tests the Court used to decide whether the draft Act was a valid exercise of federal power. Section 4 will explain the Court's rationale for deciding against the draft Act, while section 5 will conclude. The ruling shows that the jurisprudence of federalism is still alive in Canada, and that the courts will critically examine the purposes behind any proposed legislation that is challenged on the grounds of federalism.

\section{The Proposed Federal Securities Legislation}

Outlining what the proposed Act contained is useful not only to understand what the federal government proposed as its role in regulating the securities sector, but also to understand why the Court ruled against its constitutionality. The proposed Act would have created a regulatory agency called the "Canadian Securities Regula- 
tory Authority." In order to motivate and justify the federal government properly deserving a role in the regulation of securities, the preamble to the proposed Act laid out several claims. It claimed that "capital markets affect the wellbeing and prosperity of all Canadians" and that "capital markets are increasingly national and international in scope." Furthermore, because "capital markets are rapidly evolving and include increasingly complex financial products ... it is important for Canada to have ... a strengthened, comprehensive and coordinated enforcement regime for those markets."

The preamble then went on to assert that "it is in the national interest to effectively protect and promote Canadian interests internationally, including through the development of consistent regulatory policies for capital markets." These assertions then allowed the federal government to conclude that "the integrity and stability of Canada's financial system would be enhanced by ... a single Canadian securities regulator." After a long list of definitions, section 9 of the proposed Act then stated that the purposes of the Act are the protection of "investors from unfair, improper or fraudulent practices," the fostering of "fair, efficient and competitive capital markets," and the "integrity and stability of the financial system." Section 16(2) went on to explain that the "primary means for achieving" these purposes include "requirements for timely, accurate and efficient disclosure of information," the "prohibition[] of unfair, improper or fraudulent market practices," the creation of "standards for honest and responsible conduct by market participants," and "the monitoring and evaluation of issues ... affecting the integrity or stability of capital markets."

The proposed Act then lists various requirements for all sorts of securities activities. Registration requirements for securities dealers, prospectus requirements, the regulation of derivatives, mandatory disclosure requirements (for investors and by insiders), the regulation of takeover bids, and a detailed regulation of market conduct (including insider trading) which are all part of an obviously comprehensive regulatory scheme. The proposed Act also lists enforcement mechanisms, including various criminal penalties and civil liabilities. Finally, the proposed Act created an opt-in provision. This provision states that the only those provinces that agree to participate in the new federal regime will be regulated by the proposed legislation. Those provinces will have to give up their provincial control over securities in order to be regulated under the new federal Act.

The reader should note that the proposed Act looks very similar to any provincial securities legislation. Other than the preamble which describes the complexity of securities and the desirability for one regulatory standard across the country, the proposed Act is almost identical to many provincial pieces of securities legislation. This point was not lost on the Supreme Court as will be seen below.

Prior to moving on to the next section, it is worth noting that while there were several interveners in this case, they can be classified into three broad camps. The first camp was the federal government (the only party in this case) and Ontario (as well as some private interveners). The second was Alberta, Quebec, Manitoba, and New Brunswick (and some private interveners). The third was Saskatchewan and British Columbia. The first camp fully supported the proposed legislation, the second fully opposed it, and the third opposed it but in more nuanced manner than the second camp. ${ }^{8}$ The latter group argued that while the federal government could have role in the regulation of securities, it would have to respect the division of powers.

\section{The Test for the Federal Government's Jurisdiction}

In arriving at its decision, the Supreme Court first established two basic premises. The first was that the provinces have always had the jurisdiction to regulate securities. ${ }^{9}$ The second was that the federal government could claim the authority to regulate securities under the various powers listed in section 91 of the Constitution Act, $1867 .^{10}$ These include the criminal law, banking, bankruptcy, telecommunications, and peace, order and good government. The federal government, however, only chose 
to assert its jurisdiction under the regulation of trade and commerce found in section 91(2). ${ }^{11}$ The jurisdiction over trade and commerce, the Court explained, falls into two categories: 1) interprovincial and international commerce, and 2) where the national interest is "engaged in a manner that is qualitatively different from provincial concerns." 12

The first step in deciding whether the proposed Act is a constitutional exercise of power by the federal government is to look at the "pith and substance" of the proposed legislation. In other words, the Court will look at the "purpose and effects of the law to identify its "main thrust" to see whether the law truly falls into the trade and commerce category. ${ }^{13}$ Once this thrust of the legislation is established, it is then tested against the two categories outlined above. The Court explained that a long line of cases have established that the term "trade and commerce" cannot be taken as an unlimited grant of authority to the federal government. Otherwise, this would nullify the provinces' authority over property and civil rights. Therefore, a sensible balance has been established through a long line of cases. These cases refined the various tests for understanding whether an activity that was being regulated by the federal government, under the guise of trade and commerce, truly fit into that category.

The most refined version of the test, and the one the Court ultimately used in this case, is the test articulated in General Motors of Canada Ltd $v$ City National Leasing. ${ }^{14}$ The Court recited the test from General Motors as follows:

(1) whether the impugned law is part of a general regulatory scheme;

(2) whether the scheme is under the oversight of a regulatory agency;

(3) whether the legislation is concerned with trade as a whole rather than with a particular industry;

(4) whether it is of such a nature that provinces, acting alone or in concert, would be constitutionally incapable of enacting it; and

(5) whether the legislative scheme is such that the failure to include one or more provinces or localities in the scheme would jeopardize its successful operation in other parts of the country.

The Court, citing General Motors, explained that the last three factors ask whether provincial regulation by itself would be so inadequate that the absence of federal regulation created a gap in "the distribution of legislative powers." ${ }^{16}$ Another way to think about this is to ask whether the area being regulated is of national importance. By that, the Court explained, it is insufficient to simply find the area being regulated is national in nature. It has to be that even if all the provinces were regulating the area, there would still be deficiencies in the regulatory scheme. There would have to be something unique about what the federal government was doing in order to allow the federal government's jurisdiction under the guise of trade and commerce to trump the property and civil rights provincial jurisdiction.

To explain this point, the Court illustrated the tests by looking at the facts of the General Motors case itself. ${ }^{17}$ That case dealt with the constitutionality of the federally enacted competition legislation. Because economic competition is a national issue, the Court in General Motors reasoned, provinces acting alone would be unable to create a regulatory scheme that would be effective at promoting competition in the marketplace. If one province, for example, did not regulate competition, this could have adverse effects on the rest of the country. The federal government under its competition legislation, however, would not be entitled to regulate all aspects of the economy. It could only regulate the economy as it related to the laws of competition. Provinces still regulated the labour market, the market as it related to consumer protection, and other areas of the economic activity within each province. Even though the federal competition law would affect contracts created inside a province, the competition law did not purport to do a wholesale transformation of the laws governing contracts. Rather, it only affected a very specific aspect of conduct: the competitive interactions between market actors, arising out contracts formed provincially. 


\section{Applying the Test for the Federal Government's Jurisdiction to Securities}

In order to apply the five factor test from General Motors, the Court first had to look for the pith and substance of the proposed Act by looking at its purpose and effect.

To find the purpose of the proposed act, the Court looked at the "purposes" section. The stated purposes of the Act, the Court noted, were a mixed bag. ${ }^{18}$ Some, such as consumer protection, were provincial in nature, while protecting the integrity and stability of Canada's financial system were federal. ${ }^{19}$ The Court then examined the effects of the proposed legislation, both direct and "follow-through." ${ }^{20}$ The Court reasoned that the direct effect of the proposed Act is the establishment of a federal securities regulator, but that the follow-through effect is the subsuming of all of the provincial regulators. If enough provinces opt into the proposed scheme, the remaining provinces would have no choice but to follow suit. ${ }^{21}$ The result would be that whatever subject areas the proposed Act regulates would eventually become exclusively regulated federally.

This meant that the Court had to examine all the contents of the proposed Act, since if the federal Act effectively displaced the provincial counterparts, all the components of the new Act would have to be constitutionally valid. Once the Court looked at the detailed contents of proposed Act, as explained above, the Court realized that the proposed Act was nearly identical to the contents of any provincial securities legislation. Hence, the new federal Act would "duplicate legislative schemes enacted by provincial legislators exercising their jurisdiction over property and civil rights." 22

The federal government tried to defend this wholesale duplication on two grounds. The first was that there was pressing national needs that required this duplication. The second was actually some aspects of the proposed Act that were not contained in any provincial legislation. These included the control of systemic risk and the collection of national data. ${ }^{23}$ The Court agreed that these two functions could be validly ascribed to the federal government. It was possible that if the provinces were all regulating their securities markets they would not be able to deal with systemic risks nor could they properly collect national data (unless all of them came were able to enact a national agreement). That being said, the Court found that the main effect of the proposed Act was to replace all provincial securities legislation with one comprehensive federal one, albeit with one that has some distinct provisions in it.

Having found the effect of the legislation, the Court then applied the five part test from General Motors to see if it was a valid exercise of federal power. The Court immediately dispensed with the first two factors, as it was obvious that the proposed legislation is part of a regulatory scheme with a regulatory agency being created. ${ }^{24}$ The Court then examined the last three factors, namely whether this law deals with trade as a whole or a specific industry, whether the provinces acting alone or together would be unable to duplicate what the federal Act was aiming to achieve, and whether the absence of one or more provinces from a regulatory scheme would jeopardize the scheme as a whole. $^{25}$

The Court looked at the third factor first. The regulation of securities, on one hand, is the regulation of a very specific industry. One the other hand, the federal government argued, the legislation would be regulating capital, which is needed to sustain all trade. While this may be true, the Court conceded, the legislation sought to regulate all aspects of the securities industry and not just what was needed to ensure the national reach of trade facilitating capital. ${ }^{26}$ The federal government argued that since trading securities is a truly national, or even international, activity, this evolution of the industry justifies the comprehensive regulation in the proposed Act. The Court, however, did not give much credence to this argument.

The Court noted that, until now, the provinces have had no issues regulating securities despite the supposed evolution of the industry. As well, other than plain assertions, no factual evidence was presented justifying the asser- 
tion that securities are no longer an industry but represent "trade as a whole." 27 Indeed, if the industry has become so transformed, the proposed legislation should have been vastly different from the existing provincial legislation. ${ }^{28}$ The Court agreed that the provisions related to systemic risk and data collection were valid national goals but found that they did not justify a complete takeover of the provincial regulation. ${ }^{29}$

With respect to the fourth and fifth General Motors factors, the Court held that these two factors justified the federal legislation for the regulation of systemic risk and collection of national data. ${ }^{30}$ Although all the provinces could agree to collect national data, if one province were to withdraw from the agreement then the scheme would fail. Similarly, if one province did not participate or withdrew from a collective provincial agreement to deal with systemic risk, this would defeat the goals of the collective agreement. That being said, the Court held that the proposed legislation went far beyond these two goals.

Ultimately, the Court noted, the proposed legislation fundamentally deals with contracts, the protection of shareholders, market conduct, and the regulation of dealers. These are matters which fall under property and civil rights. Furthermore, the opt-in provisions also belie the federal government's claim that there is a national urgency needed for the proposed Act. The court summarized by stating:

To summarize, we accept that the economic importance and pervasive character of the securities market may, in principle, support federal intervention that is qualitatively different from what the provinces can do. However, as important as the preservation of capital markets and the maintenance of Canada's financial stability are, they do not justify a wholesale takeover of the regulation of the securities industry which is the ultimate consequence of the proposed federal legislation. The need to prevent and respond to systemic risk may support federal legislation pertaining to the national problem raised by this phenomenon, but it does not alter the basic nature of securities regulation which, as shown, remains primarily focused on local concerns of protecting investors and ensuring the fairness of the markets through regulation of participants. Viewing the Act as a whole, as we must, these local concerns remain the main thrust of the legislation-its pith and substance. ${ }^{31}$

This allowed the Court to conclude that the proposed "Securities Act as presently drafted is not valid under the general branch of the federal power to regulate trade and commerce." ${ }^{32}$

\section{Conclusion}

There are three immediate lessons from this case. The first is that the jurisprudence of federalism is still alive and well in Canada. The second is that the court will dig deep into the components of any legislation whose constitutional validity is being challenged, especially on the division of powers grounds. Here most of the proposed Act's provisions sought to regulate aspects of the economy that are already properly occupied by the provinces. Simply arguing that the world has evolved is not enough to displace their roles. The third is that the Court has a coherent jurisprudence on what constitutes a national interest in light of the third factor of the General Motors five part test.

In terms of the substance of the proposed Act, the reader should keep in mind what securities laws aim to achieve. Generally speaking, there are two main aspects to these laws. The first is disclosure requirements, and the second is governance of firms issuing securities. These two aspects are grounded in the tort of misrepresentation and fiduciary duties of directors and insiders. Admittedly the statutory schemes have enhanced and elaborated on the underlying common law. For example, insider trading was and is still not necessarily a common law violation of fiduciary duties, but is most definitely forbidden under the various statutory schemes. The old common law rule of caveat emptor also meant that it was hard to sue an issuer for misleading prospectuses, which required statutory schemes requiring more transparent disclosure. Similarly, the regulation of dealers usually goes to their legal obligations to their customers. Again, these obligations arise from concepts in fiduciary duty laws, and the statutory schemes concerning dealers augment the existing com- 
mon law duties. At the end of the day, most of what was covered by the proposed federal legislation related to these areas, which were and are still within the provincial sphere of jurisdiction of property and civil rights.

The Court's understanding of when a national area becomes part of the federal jurisdiction under the trade and commerce heading is also quite coherent. The jurisprudence of General Motors suggests that where the actions of one province can adversely affect other provinces, or the nation as a whole, then there may be a proper role for the federal government. The Court engaged in a serious analysis of whether certain aspects of the proposed draft, such as controlling systemic risk or collecting national data, could be done on a province by province basis. It also engaged in a serious analysis of the remaining aspects of the proposed draft, which are essentially what existing provincial securities legislation contains today.

The case also illustrates the challenges faced by the federal government when it enacts legislation that is set up to take over a long-standing provincial sphere of regulation. Simply asserting in the preamble the national nature of the problem will not suffice. Hard data must be presented to justify such a wholesale takeover. The five factor test from General Motors, especially the third factor, ${ }^{33}$ ultimately proved to be the downfall of this proposed legislation. The case reaffirms the importance of understanding the basics of constitutional law, namely the division of powers.

\section{Notes}

* Associate Professor, Faculty of Law, University of Alberta.

1 Reference Re Securities Act (Canada), 2011 ABCA 77 at para 2 [Securities Reference $(A B C A)]$. The term "securities" refers to financial assets such "shares in corporations, interests in partnerships, debt instruments such as bonds and financial derivatives." Securities markets can either be primary, where a company raises money by issuing securities, or secondary where the issued securities are traded among investors. Reference Re Securities Act, 2011 SCC 66 at para 40 [Securities Reference].
Constitution Act, 1867 (UK), 30 \& 31 Vict, c 3, reprinted in RSC 1985, App II, No 5; s Reference (ABCA), supra note 1 at para 2.

3 Securities Reference, supra note 1 at para 12 (citing Canada. Royal Commission on Price Spreads. Report of the Royal Commission on Price Spreads. Ottawa: King's Printer, 1935).

4 Ibid at para 13 (citing Canada. Royal Commission on Banking and Finance. Report of the Royal Commission on Banking and Finance. Ottawa: Queen's Printer, 1964).

$5 \quad$ Ibid at paras 27-28.

6 Proposed Canadian Securities Act, PC 2010-667.

$7 \quad$ Securities Reference (ABCA), supra note 1; Québec (Procureure générale) v Canada (Procureure générale), 2011 QCCA 591; Securities Reference, supra note 1.

8 Securities Reference, supra note 1 at paras 32-35. The factums for all the parties can be found at http://www.scc-csc.gc.ca/case-dossier/cms-sgd/ fac-mem-eng.aspx?cas $=33718$.

9 Ibid at paras 43-45.

10 Ibid at para 46.

11 Ibid at para 47.

12 Ibid at para 47. The leading case that started the line of cases explaining the trade and commerce jurisdiction is Citizens Insurance Co. of Canada v. Parsons (1881), 7 App Cas 96.

13 Securities Reference, supra note 1 at 63 [emphasis in original].

14 [1989] 1 SCR 641 [General Motors].

15 Securities Reference, supra note 1 at para 80.

16 Ibid at para 81.

17 Ibid at paras 87-89.

$18 \quad$ Ibid at para 97.

19 Ibid.

$20 \quad$ Ibid at para 98.

$21 \quad$ Ibid at para. 99.

$22 \quad$ Ibid at para 101.

23 Ibid at para 102. Systemic risk is risk that affects the country as a whole and that cannot be controlled at a local level, ibid at para 103.

24 Ibid at para 110.

25 Ibid at paras 111-123.

26 Ibid at para 114.

27 Ibid at para 115.

28 Ibid at para 116.

$29 \quad$ Ibid at para 117.

30 Ibid at paras 120-123.

31 Ibid at para 128.

32 Ibid at para 134.

33 For more details see Malcolm Lavoie, "Understanding 'Trade as a Whole' in the Securities Reference," UBC L Rev, Vol. 46, No. 1, 2013. 